\title{
Effects of the Climate Change on Peripheral Populations of Hydrophytes: A Sensitivity Analysis for European Plant Species Based on Climate Preferences
}

\author{
Ricardo Enrique Hernández-Lambraño ${ }^{1,2, *}$, David Rodríguez de la Cruz ${ }^{1,2}$ and José Ángel Sánchez Agudo ${ }^{1,2}$ \\ 1 Grupo de Investigación en Biodiversidad, Diversidad humana y Biología de la Conservación, \\ Campus Miguel de Unamuno, Universidad de Salamanca, s/n, E-37007 Salamanca, Spain; \\ droc@usal.es (D.R.d.1.C.); jasagudo@usal.es (J.Á.S.A.) \\ 2 Departamento de Botánica y Fisiología Vegetal, Área de Botánica, Campus Miguel de Unamuno, \\ Universidad de Salamanca, s/n, E-37007 Salamanca, Spain \\ * Correspondence: ricardohl123@usal.es
}

\section{check for} updates

Citation: Hernández-Lambraño, R.E.; de la Cruz, D.R.; Agudo, J.Á.S Effects of the Climate Change on Peripheral Populations of Hydrophytes: A Sensitivity Analysis for European Plant Species Based on Climate Preferences. Sustainability 2021, 13, 3147. https://doi.org/ $10.3390 /$ su13063147

Academic Editors: Gioele Capillo and Ivo Machar

Received: 22 January 2021

Accepted: 10 March 2021

Published: 12 March 2021

Publisher's Note: MDPI stays neutral with regard to jurisdictional claims in published maps and institutional affiliations.

Copyright: (c) 2021 by the authors. Licensee MDPI, Basel, Switzerland. This article is an open access article distributed under the terms and conditions of the Creative Commons Attribution (CC BY) license (https:// creativecommons.org/licenses/by/ $4.0 /)$.

\begin{abstract}
Biogeographical theory suggests that widespread retractions of species' rear edges are expected due to anthropogenic climate change, affecting in a particularly intense way those linked to fragile habitats, such as species' rear edges closely dependent on specific water conditions. In this way, this paper studies the potential effects of anthropogenic climate change on distribution patterns of threatened rear edge populations of five European hydrophyte plants distributed in the Iberian Peninsula. We explored (i) whether these populations occur at the limit of the species' climatic tolerance, (ii) we quantified their geographic patterns of vulnerability to climate change, and in addition, (iii) we identified in a spatially explicit way whether these threatened populations occur in vulnerable environments to climate change. To do this, we simulated the climatic niche of five hydrophyte species using an ecological modelling approach based on occurrences and a set of readily available climatic data. Our results show that the Iberian populations studied tended to occur in less suitable environments relative to each of the species' optimal climates. This result suggests a plausible explanation for the current degree of stagnancy or regression experienced by these populations which showed high sensitivity and thus vulnerability to thermal extremes and high seasonality of wet and temperature. Climatic predictions for 2050 displayed that most of the examined populations will tend to occur in situations of environmental risk in the Iberian Peninsula. This result suggests that the actions aimed at the conservation of these populations should be prioritized in the geographic locations in which vulnerability is greatest.
\end{abstract}

Keywords: sensitivity; vulnerability; threatened species; hydrophyte plants; species' rear edges; climatic change; MaxEnt; CENFA

\section{Introduction}

Biodiversity of freshwater habitats, especially in relation to wetland plants, is of conservation concern world-wide [1,2]. These species are threatened by multiple factors. Climate and land use changes are standing out and are the most important factors $[3,4]$. Risk of extinction due to anthropogenic climate change is a significant threat for these species [2], especially those populations inhabiting at the rear range edge [5].

Biogeographical theory suggests that widespread retractions of species' rear edges should be seen in response to anthropogenic climate change [5,6]. Indeed, climate is considered the most important driver of plant species distribution, with temperature mostly affecting the upper elevation/latitude edges and water availability the low elevation/latitude edges [7]. In this way, it is reasonable to expect that population loss and range retractions should be seen in the most drought-prone areas of a species' distribution [8]. This prediction is based on the fact that rear edge populations often occur at the limit of the 
species' ecological tolerance. Thus, they habitually occupy less favourable habitats $[9,10]$ and are expected to decline in performance as climate warming pushes them to extirpation $[5,11]$, although empirical evidence remains rare [12]. The study of these populations are critically important for the long-term conservation of genetic diversity, phylogenetic history, evolutionary potential, and species' response to ongoing climate change [6]. In this sense, identifying the vulnerability of threatened rear edge populations to climate change is vital for guiding effective conservation efforts [13].

Williams et al. [14] describe three fundamental aspects of the vulnerability of a species or individuals to climate change: (i) sensitivity, as the degree to which the species' persistence ability is determined by the climatic conditions of its habitat; (ii) exposure, as the degree to which the species will experience climate change across its distribution range; and finally (iii) adaptive capacity, as the ability to adapt to changes in climate, through dispersal, evolutionary responses, and phenotypic plasticity [15]. Under this scenario, climate-niche models based on ecological niche theory [16] may offer a spatially-explicit insight into geographic patterns of species vulnerability (e.g., sensitivity and exposure) to climate change. This approach uses known occurrence locations and spatially-explicit data on the environmental conditions believed to restrict the geographic distribution of the target species to predict habitat suitability across the landscape [17]. In recent years, a novel approach to model the species' climate niche based on Hutchinson's concepts, termed Climate-Niche Factor Analysis (CNFA), was proposed by Rinnan and Lawler [15]. CNFA quantifies species marginality and the specialization relative to the global distribution [18] and provides a spatially-explicit insight into geographic patterns of species vulnerability to climate change [15].

A particularly interesting situation for the study of the effects of the anthropogenic climate change on the persistence ability of threatened species populations living in the rear edge range concerns the hydrophytic flora of the Iberian Peninsula, where many Central European species occur at their northern range limits, often in peripheral isolates [19]. This pattern is closely associated with the climatic and geological history of the region with an important role of migratory processes caused by glacial and interglacial periods [20]. For this study we selected hydrophyte plants since it is known that aquatic and wetland habitats are among the most threatened worldwide mainly due to hydrological system alterations, especially those derived from global warming, pollution, and invasive species [21,22]. Moreover, many of these taxa are very scarce in the Iberian Peninsula and therefore have been included in the Red List of the Vascular Flora of Spain and Portugal [23-25]. Based on a comparative analysis of such species $(n=5)$, the aims of this paper are threefold: (i) we test whether threatened populations living on the rear range edge occur at the limit of the species' climatic tolerance; (ii) we quantify the geographic patterns of vulnerability to climate change; (iii) we attempt to identify in a spatially explicit way whether threatened rear edge populations occur in vulnerable habitats to climate change.

\section{Materials and Methods}

\subsection{Study Species}

Five hydrophyte plant species of the European Flora were selected to carry out this study (Table 1). Each of them has a different range of distribution, but they all have in common that they reach the Iberian Peninsula marginally with only a few populations which constitute the western limit of their European distribution range [19]. Moreover, due to the species' rarity within the Iberian territory, they are included in the Red List of the Vascular Flora [23-25]. We based our selection on listed species because their distribution is solidly documented [19] and also because of their conservation significance.

\subsection{Study Area and Dataset}

The study area covers most of Continental Europe including the British Islands. The limits used are according to those defined by Flora Europaea [27], excluding Iceland, Faroe Islands, Svalbard, and Novaya Zemlya (Figure 1). Partial territories in the Russian Federa- 
tion west of the Urals were also included [9]. The Iberian Peninsula was established a priori as a geographical marginal territory due to its latitude, orographical and climatic characteristics. In addition, this territory has historically been one of the major Mediterranean refugia for Central European species [20].

Table 1. List of studied species, their biological features, and species' threat category.

\begin{tabular}{|c|c|c|c|c|}
\hline Species & $\begin{array}{l}\text { Flowering } \\
\text { Month }\end{array}$ & $\begin{array}{l}\text { Biological } \\
\text { Type }\end{array}$ & $\begin{array}{l}\text { Iberian Threat } \\
\text { Category }\end{array}$ & $\begin{array}{l}\text { IUCN Global } \\
\text { Category }\end{array}$ \\
\hline $\begin{array}{c}\text { Callitriche platycarpa Kütz. in Rchb. } \\
\text { Eleocharis austriaca Hayek }\end{array}$ & Early-summer & Hydrophyte & VU & $\mathrm{LC}$ \\
\hline $\begin{array}{c}\text { (=Eleocharis mamillata subsp. austriaca } \\
\text { (Hayek) Strandh.) }\end{array}$ & Late-spring & Hydrophyte, Geophyte & CR & $\mathrm{LC}$ \\
\hline Luronium natans (L.) Raf. & Mid-summer & Hydrophyte, Herb & EN & LC \\
\hline Nymphoides peltata (S.G. Gmel.) O. Kuntze & Mid-summer & Hydrophyte, Herb & $\mathrm{CR}, \mathrm{EN}$ & $\mathrm{LC}$ \\
\hline Rumex hydrolapathum Huds. & Late-spring & Hydrophyte, Herb & CR & LC \\
\hline
\end{tabular}

Note: Iberian red list category according to the Spanish and Portuguese legislations (EN, endangered; CR, critically endangered; VU, vulnerable) [23-25] and to the IUCN global red list category (LC, least concern) [26].
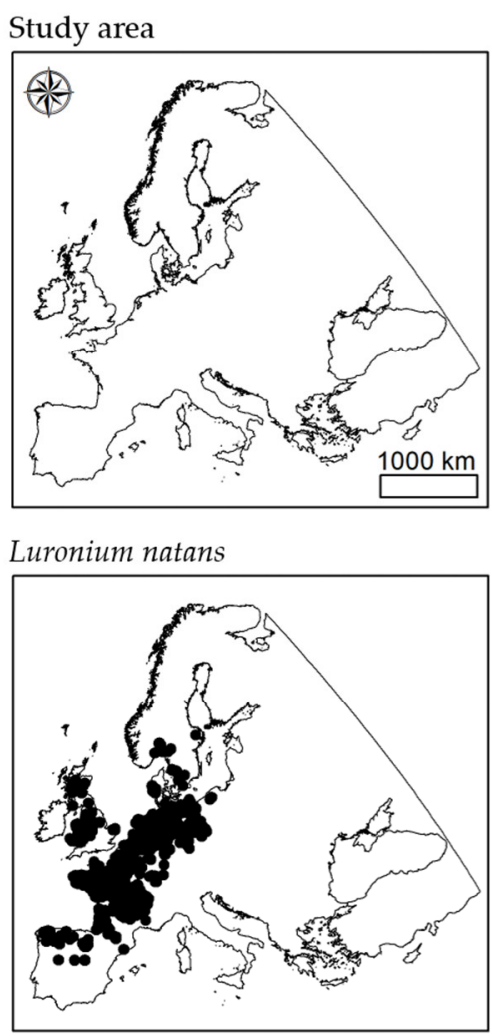
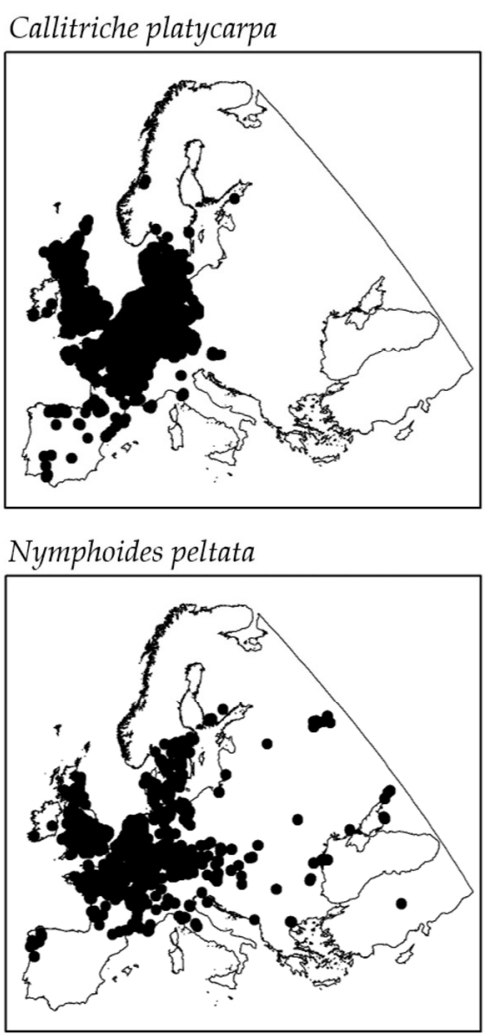
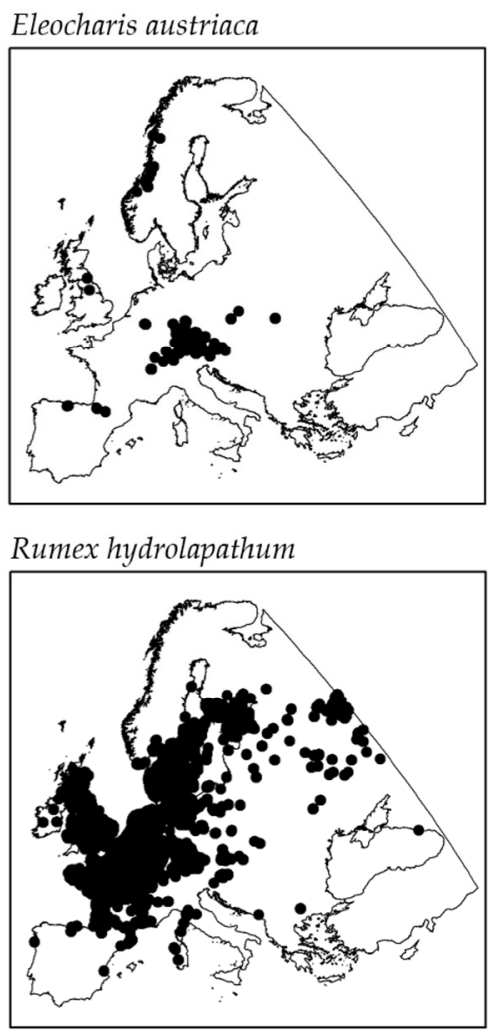

Figure 1. Occurrence records per analyzed species in the study area.

Data on the geographical distributions of the study species (Figure 1) were compiled from the Global Biodiversity Information Facility (GBIF; www.gbif.org (accessed on 3 June 2019)). The dataset was cleaned manually so that only high-quality records were used in the analysis; records conforming to these sets of conditions were retained: (i) georeferenced; (ii) with year of record; (iii) with "county" or "municipality" locality data; (iv) inland coordinates; (v) and inside the known native range of the species, as depicted by species range maps of Figure 1 . We used a grid resolution of $1 \times 1 \mathrm{~km}$ to remove duplicate records (i.e., only one occurrence record per grid square of $1 \times 1 \mathrm{~km}$ ), thereby reducing clustering (spatial bias; [28]). We omit occurrence data outside the years 1979-2013 to align with the temporal reference of the climatic variables (described below). 
For our analysis, climatic variables of the current climate (representative of 1973-2013) were downloaded from the climatologies at high resolution for the Earth's land surface areas (CHELSA; http: / / chelsa-climate.org / (accessed on 3 June 2019)) database at a 30 arcsecond resolution $(\sim 900 \mathrm{~m})$. This dataset provides improved climatic estimates in landscapes with complex topography [29]. We chose four bioclimate variables (Table 2 and Figure A2) to represent a broad range of seasonal and annual climatic patterns across the study area while minimizing redundancy (Figure A1). These variables were chosen because of their strong link with important ecological processes in plant species, such as distribution, reproduction, and phenology [30]. Furthermore, these variables are enough to explain most of the climatic variation, and other important variables (e.g., winter and summer temperatures) are strongly related to linear combinations of the four variables considered. Climate data were aggregated by averaging to $1 \times 1 \mathrm{~km}$ to match the species data grid. All spatial information processing was handled using ArcGIS 10.3 [31].

Table 2. Bioclimatic variables used for this study, obtained from the CHELSA database [29], and calculated from monthly air temperature means and precipitation sums.

\begin{tabular}{cccc}
\hline Variable & Calculation & Unit & Source \\
\hline $\begin{array}{c}\text { Annual mean temperature } \\
\text { Temperature seasonality }\end{array}$ & $\left(\sqrt{\frac{\sum_{i=1}^{12} t_{i}}{12} \sum_{i=1}^{12}\left(t_{i}-\left(\sum_{i=1}^{12} \frac{t_{1}}{12}\right)\right)^{2}}\right)$ & ${ }^{\circ} \mathrm{C}$ & CHELSA [29] \\
Annual precipitation & $\sum_{i=1}^{12} p_{i}$ & $\mathrm{SD}$ & $\mathrm{mm}$ \\
Precipitation seasonality & $\left(\sqrt{\frac{1}{11} \sum_{i=1}^{12}\left(p_{i}-\left(\sum_{i=1}^{12} \frac{p_{i}}{12}\right)\right)^{2}}\right) /\left(\frac{\sum_{i=1}^{12} p_{i}}{12}\right)$ & $\mathrm{CV}$ & \\
\hline
\end{tabular}

$t_{i}=$ monthly temperature, $p_{i}=$ monthly precipitation, $\mathrm{SD}=$ standard deviation and $\mathrm{CV}=$ coefficient of variation.

For future climate (2050: average of 2041-2060), we used an ensemble method of two global climate models (GCMs) due to climate uncertainty [32,33]. The two GCMs used were the Community Climate System Model (CCSM4) [34] and the Hadley Global Environment Model (HadGEM2-ES) [35]. Both models have been used extensively in addressing the effects of climate change on species distributions [36]. For the future climate ensembles, we used two representative concentration pathways (RCPs) for the prescribed greenhouse gas emissions: (i) RCP 4.5, which represents medium $\mathrm{CO}_{2}$ emissions; (ii) and RCP 8.5, which represents high $\mathrm{CO}_{2}$ emissions [37]. The future climate data were downloaded from the CHELSA dataset at a 30 arc-second resolution and were aggregated by averaging to $1 \times 1 \mathrm{~km}$ to match the species data grid (Figure A2).

In relation to projections of the effects of future climate change for European regions, the Iberian Peninsula has been identified as one of the areas that is most vulnerable to the predicted changes $[38,39]$ and is expected to experience greater increases in temperature and aridity than other regions. In this sense, we evaluated spatial changes in the Iberian Peninsula climate characteristics through the differences between the future climate and the current climate.

\subsection{Modelling Climatic Suitability}

To assay whether threatened populations living on the Iberian Peninsula occur at the limit of the species' climatic tolerance we used the ecological-niche model. This approach uses known occurrence locations and spatially-explicit data on the environmental conditions (herein climatic variables) believed to restrict the geographic distribution of the target species to predict climatic suitability across the landscape [17]. To do it, we used the maximum entropy (MaxEnt) modeling [40]. MaxEnt is a machine-learning process that uses presence-only data and environmental covariates to estimate the relative suitability of one place vs. another [41]. MaxEnt has been described as especially efficient to handle 
complex interactions between response and covariates [41,42], and to be little sensitive to small sample sizes [43]. We used this method because it has been demonstrated to perform well in a diverse set of modeling scenarios in ecology, biogeography, and conservation, besides being widely used to fit models across many different taxa, geographical areas, and time periods [44,45].

To build the climatic-niche models for each of the species, we used the kuenm package in R [46]. This tool allows detailed calibrations of ecological-niche models in Maxent, helping to select among the complex and numerous sets of parameters those that demonstrate best performance based on significance, predictive ability, and complexity level [46]. In this study, for each species, we created 493 candidate models by combining 1 set of climatic predictors, 17 values of the regularization multiplier (0.1-1.0 at intervals of $0.1,2-6$ at intervals of 1,8 , and 10), and all 29 possible combinations of the 5 feature classes (linear $=1$, quadratic $=q$, product $=\mathrm{p}$, threshold $=\mathrm{t}$, and hinge $=\mathrm{h}$ ). We evaluated the candidate model performance based on significance (partial ROC, with 500 iterations and $50 \%$ of the data for bootstrapping), omission rates $(E=5 \%)$, and model complexity (AICc). Best models for each species were selected according to the following criteria: (i) significant models with (ii) omission rates $\leq 5 \%$. Then, from among this model set, models with delta AICc values of $\leq 2$ were chosen as final models. The candidate model creation was performed using the "kuenm_cal" function and the candidate model evaluation and the best model selection was done using the "kuenm_ceval" function.

We created final models (i.e., the best fitted model for each species) using the full set of occurrences and the selected parameterizations (Table 2). We produced 10 replicates by bootstrap with logistic outputs. The final model evaluations consisted of calculations of partial ROC, omission rates, and AICc using an independent dataset. Final models were performed with the "kuenm_mod" function. Finally, we extracted habitat suitability values from the final model for the threatened species populations inhabiting the Iberian Peninsula.

\subsection{Modelling Vulnerability to Climate Change}

Species' vulnerability can be interpreted as a function of both extrinsic (exposure) and intrinsic (sensitivity and adaptability) traits [14,47]. Exposure is the degree to which the species will experience climate change across its distribution range [14]. Sensitivity is the degree to which the species' persistence ability is determined by the climatic conditions of its habitat, while adaptability is the ability to adapt to changes in climate through dispersal, evolutionary responses, and phenotypic plasticity $[14,15]$. In this study adaptability was not considered, as climatic niche evolution of species is slower than the rate of climate change [48].

We used the CNFA approach [15] to quantify vulnerability to climate change of five species of hydrophyte plants with threatened populations living on the Iberian Peninsula. This approach expands on the earlier ecological-niche factor analysis [18,49], provides spatially-explicit insight into geographic patterns of vulnerability, relies only on readilyavailable spatial data, and is suitable for a wide range of species and habitats [15]. One of the strengths of this approach is the ability to identify and describe aspects of climate vulnerability to climate change with relatively little information about the species itself [15]. Thus, this enables us to more proactively identify species of highest climate vulnerability and species in need of immediate conservation actions. We used this approach because it has been demonstrated to perform well in different taxa and geographical areas [15,50-52].

To quantify CNFA models we compared the species distribution in the ecological space with the global distribution of available environmental conditions [15]. We quantified two aspects of a species' niche: (i) the marginality axis $(m)$, which is a measurement capturing the difference between the conditions used by the species and the conditions available in the global distribution and (ii) specialization axis $(p)$, which is the ratio of size of the species niche to that of the global distribution [15]. To define the global distribution in our study, we used the combined range of the five hydrophyte species in Europe as $\mathrm{N}$ cells. For the distribution of each species with $\mathrm{N}$ cells, we used occurrence records. For the 
multi-dimensional ecological space composed of bioclimatic variables with $C$ dimensions, the components of marginality and specialization are defined as the marginality factors $\left(m_{j}\right)$ and the specialization factors $\left(p_{j 1}, p_{j 2}, \ldots, p_{j C-1}\right)$, respectively. Based on the first factor, we extracted the marginality values for the threatened populations of each species in order to identify how far the climatic conditions used for such populations are from the optimal climatic conditions for the global distribution.

Following Rinnan and Lawler [15], we measured the following metrics: sensitivity $(s)$, exposure $(e)$, and vulnerability $(v)$ of each species to climate change. We obtained the sensitivity factor through the marginality and specialization axis for each bioclimatic variable. We first normalized the vector $\left(m_{j}, p_{j 1}, p_{j 2}, \ldots, p_{j C-1}\right)$ to $\left(w_{j 1}, w_{j 2}, \ldots, w_{j C}\right)$. We then calculated the sensitivity factor $s_{j}$ corresponding to each bioclimatic variable $j$ as $\sum_{k=1}^{C} w_{j k} \rho_{k}$, where $\rho_{1}$ is the amount of specialization on the marginality axis, and $\rho_{k}(k>1)$ is the amount of specialization expressed on the specialization axis. The $s$ metric quantifies the average species specialization in each climatic variable. Thus, if a species only tolerates a narrow range of climatic conditions, we may reasonably expect it to be more sensitive to the effects of climate change. The overall sensitivity $s=\sqrt{1 / C \sum_{j=1}^{C} s_{j}}$, can then be used to compare the sensitivity between different species.

The $e$ metric quantifies the differences between current and future conditions (departure) inside the species range. In this sense, this metric reflects the amount of climate change a species might experience if it remains in place. The departure factor is $d_{j}=\sum_{i=1}^{N} p_{j}\left|\delta_{i j}-z_{i j}\right|$, where $\delta_{i j}$ and $z_{i j}$ represents the value of current and future bioclimatic variable $j$ at location $i$, respectively, and $p_{i}$ is the habitat utilization at location $i$. Then, the overall exposure is $e=\sqrt{\sum_{j=1}^{C} d_{j}^{2}}$.

Finally, to calculate the species vulnerability to climate change, we combined sensitivity and exposure. To do this, we calculated the vulnerability factor $v_{j}$ for each bioclimatic variable $j$ as $\sqrt{\left(1+d_{j}\right) s_{j}}$, and the predicted vulnerability of cell $i$ for the global distribution as $v_{G i}=\sqrt{\sigma_{G i} \varepsilon_{G i}}$. Thus, the overall vulnerability is $v=\sqrt{1 / C \sum_{j=1}^{C} v_{j}}$. The $v$ metric reflects the interaction between $s$ and $e$ to climate change. Larger values of $s$ and $e$ indicate higher climate sensitivity and exposure, which result in larger $v$ values, indicating higher vulnerability in the climatic variable. See [15] for more thorough details on the CNFA process.

We implemented the CNFA method with the "cnfa" function of the package CENFA [15] in the R program [53]. We also used the "predict" function in the CENFA package to evaluate the spatial vulnerability within a potential habitat used by the threatened populations living on the Iberian Peninsula. To select the potential habitat, we used the minimum convex polygon (convex hull) produced by the full set of presence records for each species in the Iberian Peninsula. Maps of spatial vulnerability were generated with ArcGIS [31].

\section{Results}

\subsection{Projected Changes in the Iberian Peninsula Climate Characteristics}

Analysis of projected changes in the climate variables used in this study showed that the Iberian Peninsula is very likely to undergo warmer and drought events (Figure 2). These changes present similar spatial patterns for the near future (2050) under the scenarios RCPs 4.5 and 8.5. On the one hand, annual patterns of temperature are projected to increase overall on the peninsula, especially in the mountain zones. On the other hand, for the annual patterns of precipitation a decrease over the entire peninsula is projected, especially in the north and northwest. Finally, seasonal patterns of temperature and precipitation are projected to increase throughout the peninsula.

\subsection{Climatic Suitability}

The final best models for each species performed well in throughout the study area according to the external validations (Table 3). 

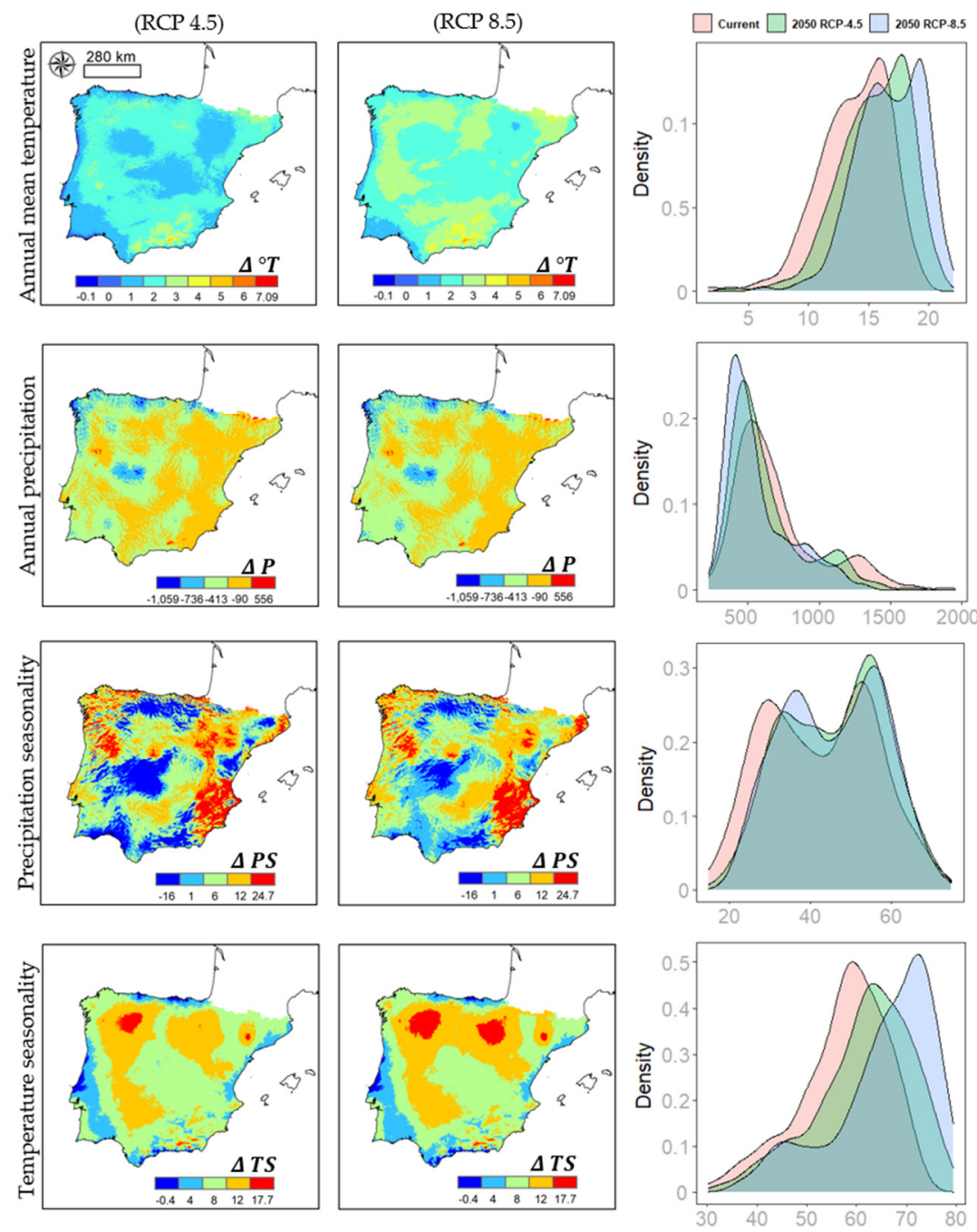

Figure 2. The first two columns are spatial differences between Iberian Peninsula climate variables for the future period (2050: average of 2041-2060) and the current period (average of 1973-2013). The third column is the distribution of climate variables throughout the Iberian Peninsula. The future climate scenario was estimated from an ensemble of two global climate models projections under the representative concentration pathways (RCPs) 4.5 and 8.5. TS and PS: temperature and precipitation seasonality, respectively.

Table 3. Final models performance for each species under optimal parameters. Feature classes (linear $=1$, quadratic $=q$, product $=\mathrm{p}$, threshold $=\mathrm{t}$, and hinge $=\mathrm{h}$ ).

\begin{tabular}{|c|c|c|c|c|c|c|}
\hline Species & $\begin{array}{l}\text { Regularization } \\
\text { Multiplier }\end{array}$ & $\begin{array}{l}\text { Feature } \\
\text { Classes }\end{array}$ & $\begin{array}{c}\text { Mean AUC } \\
\text { Ratio }\end{array}$ & Partial ROC & $\begin{array}{c}\text { Omission Rate } \\
(5 \%)\end{array}$ & AICc \\
\hline Luronium natans & 0.5 & lqp & 1.15 & 0.01 & 0.045 & 346.46 \\
\hline $\begin{array}{c}\text { Rumex } \\
\text { hydrolapathum }\end{array}$ & 2 & lqph & 1.28 & 0.00 & 0.030 & 985.65 \\
\hline $\begin{array}{l}\text { Nymphoides } \\
\text { peltata }\end{array}$ & 0.1 & lqp & 1.22 & 0.02 & 0.049 & 458.27 \\
\hline $\begin{array}{l}\text { Callitriche } \\
\text { platycarpa }\end{array}$ & 0.1 & lqp & 1.19 & 0.01 & 0.023 & 248.13 \\
\hline $\begin{array}{l}\text { Eleocharis } \\
\text { austriaca }\end{array}$ & 0.7 & lq & 1.16 & 0.02 & 0.041 & 148.13 \\
\hline
\end{tabular}

These results indicate high dependence on the occurrence data and the set of climatic variables included in the analysis. In relation to the optimal climates of the analyzed 
species, the threatened populations of all species tend to occur in less climatic suitable habitats on the Iberian Peninsula (Figure 3).

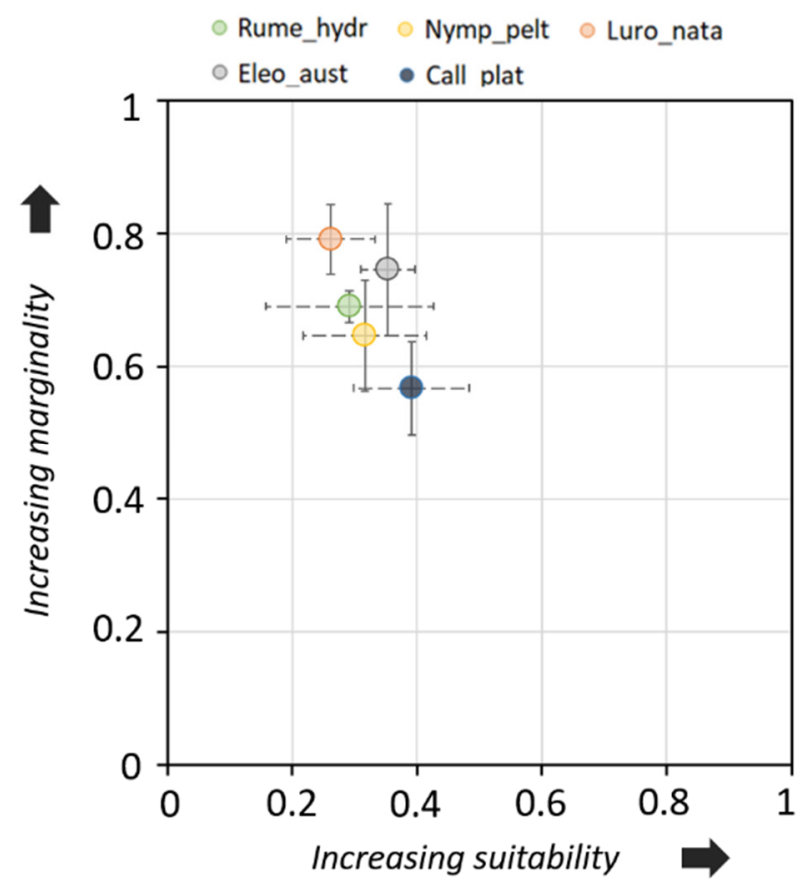

Figure 3. Mean suitability vs. mean marginality for all species. The grey bars are standard errors reflecting variation for marginality and grey dashed bars are standard errors reflecting variation for habitat suitability. Rume_hydr, Rumex hydrolapathum; Nymp_pelt, Nymphoides peltate; Luro_nata, Luronium natans; Eleo_aust, Eleocharis austriaca; Call_plat, Callitriche platycarpa.

\subsection{Vulnerability to Climate Change}

Application of the CNFA method to the calibration set indicated that only two axes (i.e., the axis of marginality and the first axis of specialization) accounted for most of the information for all species studied. The five species have high overall marginality indexes (Table 4). These results show that the niche of the species differs clearly from the mean conditions in their global distributions.

Table 4. Overall marginality $(m)$, sensitivity $(s)$, exposure $(e)$, and vulnerability $(v)$ of five hydrophyte species in the study area under future climate for the year 2050. The future climate scenarios were estimated from ensembles of two global climate models projections under the representative concentration pathways (RCPs) 4.5 and 8.5.

\begin{tabular}{|c|c|c|c|c|c|c|}
\hline Species & $m$ & $s$ & $e(\mathrm{RCP} 4.5)$ & $e(\mathrm{RCP} 8.5)$ & $v(\operatorname{RCP} 4.5)$ & $v(\mathrm{RCP} 8.5)$ \\
\hline Luronium natans & 2.16 & 3.81 & 0.43 & 0.74 & 2.00 & 2.07 \\
\hline Rumex hydrolapathum & 1.98 & 3.36 & 0.43 & 0.73 & 1.91 & 1.97 \\
\hline Nymphoides peltata & 2.08 & 2.95 & 0.44 & 0.75 & 1.79 & 1.85 \\
\hline Callitriche platycarpa & 2.06 & 2.86 & 0.43 & 0.68 & 1.74 & 1.79 \\
\hline Eleocharis austriaca & 2.12 & 1.92 & 0.37 & 1.08 & 1.44 & 1.53 \\
\hline
\end{tabular}

Marginality coefficients point out that species are essentially linked to wets and less seasonality environments (see $m$ factor in Figure 4). Climatic conditions of the populations living on the Iberian Peninsula were rather different from the mean available conditions (Figure 3), indicating that these marginal populations tended to occur in less suitable climatic environments relative to each of the species' optimal climates.

The factor account for specialization (see $p$ factor in Figure 4), mostly regarding annual mean temperature and precipitation seasonality, indicates some species' sensitivity to shift away from the optimal values of these variables. In fact, the overall sensitivity 
index (Table 4) shows that the ranges of species' tolerable climate conditions are quite restricted, with the greatest sensitivity to hot temperature extremes and high fluctuations in precipitation (i.e., high seasonality) (see $s$ factor in Figure 4).

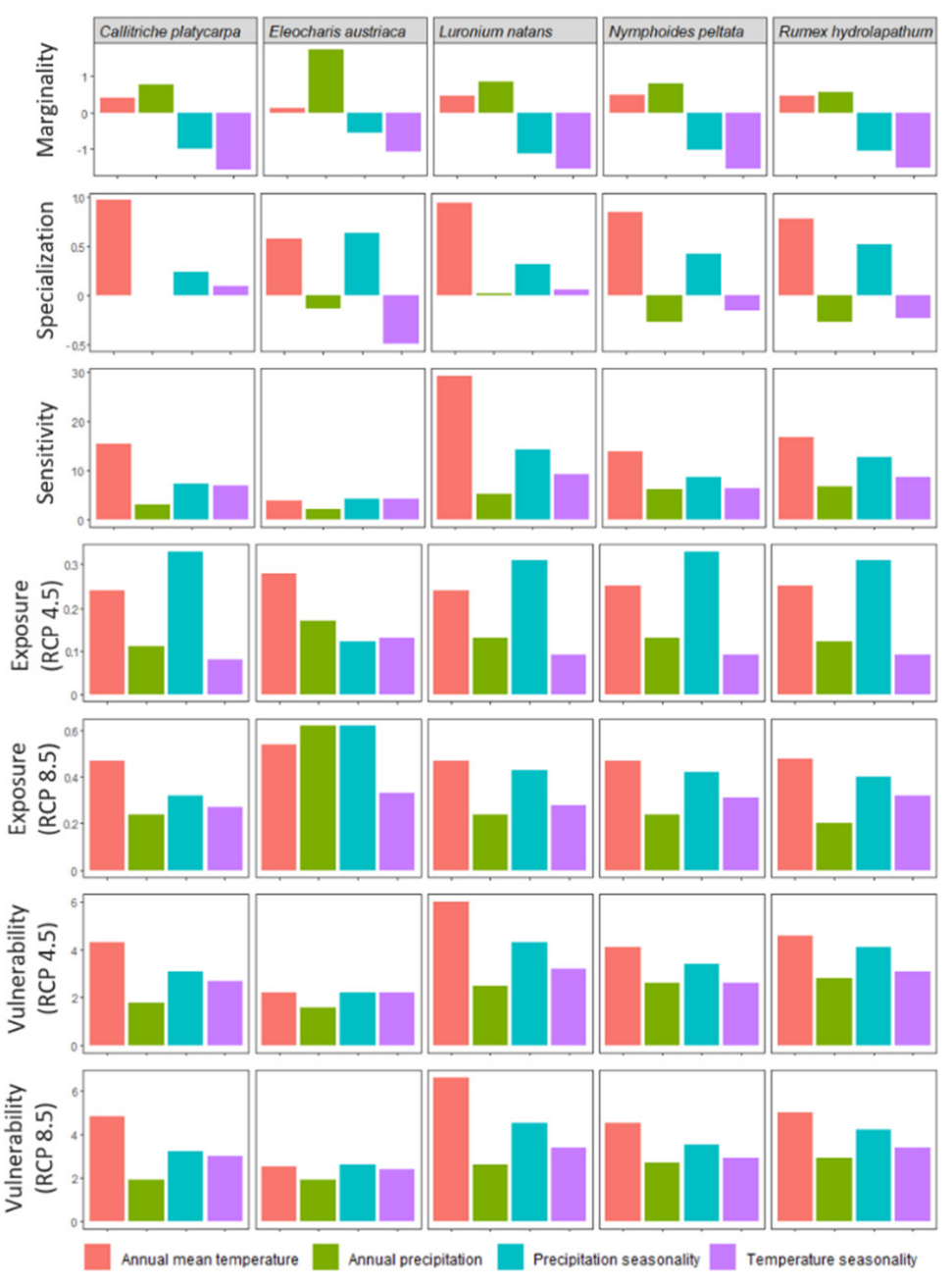

Figure 4. The marginality factor, specialization factor, sensitivity factor, exposure factor, and vulnerability factor of five hydrophytes species for four bioclimatic variables calculated under future climate for the year 2050 as estimated from an ensemble of two global climate models projections under the representative concentration pathways (RCPs) 4.5 and 8.5 .

The RCP 8.5 scenario had greater departure than the RCP 4.5 scenario in almost every variable, reflecting the expected increase in climate change associated with the concentration of greenhouse gas emissions. The five species had high departure indexes, hence, this led to high overall vulnerability indexes (Table 4). In general, the species studied demonstrated high vulnerability to thermal extremes and high seasonality of precipitation and temperature (see $v$ factor in Figure 4).

For the five species, the overall vulnerability index under RCP 8.5 is higher than those under RCP 4.5 (Table 4). Compared with the other hydrophyte species, L. natans and $R$. hydrolapathum have the highest overall vulnerability to climate change, followed by N. peltata, C. platycarpa, while E. austriaca shows the least overall vulnerability (Table 4). The different $\mathrm{CO}_{2}$ emission scenarios do not change the vulnerability ranking for the five hydrophyte species.

The most vulnerable current environments for the hydrophyte threatened populations taking into account future climatic projections for the Iberian Peninsula are shown in the Figures 5 and A3. Overall, most of the examined populations occur in environments that will undergo significant climatic changes (Figures 5 and A3). The spatial patterns of climatic 
vulnerability under RCP 4.5 show a similar pattern for RCP 8.5 (Figures 5 and A3). However, the high $\mathrm{CO}_{2}$ emission increases the climatic vulnerability for the studied populations (Figure 5). These results also allow us to detect areas that can serve as a refuge from climatic disturbances. Thus, the predictions suggest that the northeast zones of both hydrographic basins of the Duero and Ebro may provide potential suitable refuges from climate change for R. hydrolapathum, L. natans and C. platycarpa. For N. peltata and E. austriaca, climate refuges could be located in zones adjacent to the hydrographic basins of the Miño and Pais Vasco, respectively.
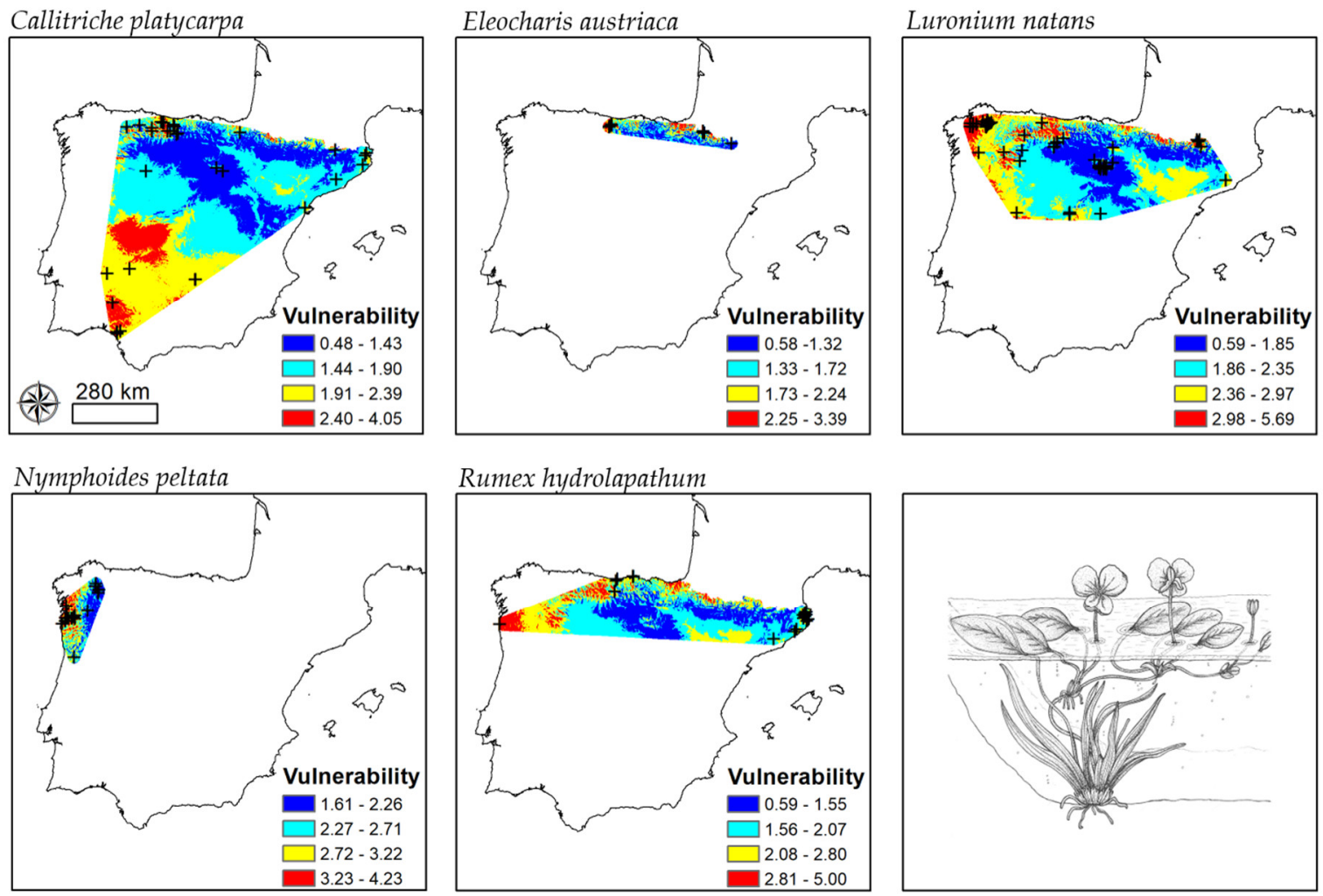

Figure 5. Predicted vulnerability across the potential habitat used by the threatened populations living on the Iberian Peninsula. The future climate scenario was estimated from an ensemble of two global climate model projections under the representative concentration pathway (RCP) 8.5 (year 2050). Predicted vulnerability for RCP 4.5, see Figure A3.

\section{Discussion}

\subsection{Vulnerability to Climatic Change}

In this study, we apply a niche-based ecological model in an attempt to explicitly assess the potential effects of the climate change on the distribution patterns of species' rear edges. In this case, hydrophytic plants were ideal due to their specific ecological requirements. In recent years, niche-based ecological models have become a strong approach for addressing this conservation issues at large scales $[9,15]$. This approach can provide useful information in order to lead priority conservation plans to endangered populations in a timely manner, when there is a lack of updated data about the real degree of threat for these populations, and the available resources for practical conservation actions are scarce [9].

In this study, we have found a correspondence between ecological (i.e., climatic) and geographical marginality for threatened rear edge populations of some European hydrophytes on the Iberian Peninsula. These results would support the hypothesis that marginality within the set of habitable conditions (i.e., climate niche) could represent an outstanding factor on the performance and thus persistence of isolated plant populations. Less availability of suitable environments at their rear edge distribution ranges could be translated into lower survival potential for these populations [5]. The optimal climatic 
habitats for our target species are associated with colder, wetter, and less seasonal environments and, for the Iberian Peninsula, these conditions are linked to high mountain habitats with high water regimes and low temperatures. However, due to the warmer, less wet, and more seasonal climates of this area in relation to Northern European climates, the suitable environments of the Iberian populations seem to be lower than the mean values in the rest of their distribution. According to these results, marginality in the Iberian populations of these species are particularly highlighted. Numerous studies provide empirical evidence of an important rear edge population decline. For example, Allen et al. [54] report range retractions and population decline (i.e., mortality) associated with elevated drought stress at species' rear edges in forest ecosystems across the globe. However, this rear edge population decline has been often questioned by empirical data [55]. These mismatches can occur, for instance, if peripheral populations are genetically isolated and adapted to conditions in border areas [56], their ecological optima are not properly established [57], their original patterns have been altered by anthropogenic land use changes [5], or their distribution patterns occur in suitable environmental conditions (i.e., microrefugium) surrounded by inhospitable regional climate [9]. On the other hand, many of the threatened populations of the analyzed species are distributed in a scattered way with few populations throughout the Iberian Peninsula. Some of them are also associated with anthropogenic activities that would make them especially vulnerable. In fact, in the Iberian territory, the distribution areas of these populations are subject to a strong anthropogenic pressure due to the conditioning of river banks, the construction of river walks, the transformation of water courses, the drainage of the water table, and livestock [24]. These factors may increase fragmentation and isolation, which can result in a significant population decline [6].

Our results indicate that the studied species have narrower climate niches, suggesting that they may be very sensitive to climate change. In fact, the two largest components of the species sensitivity factor are all associated with colder, wetter, and less seasonal environments. Analysis of projected changes in the climate variables used in this study showed that the Iberian Peninsula is very likely to undergo significant climatic changes. These changes display similar spatial patterns for the near future (2050) with increase of the temperatures and droughts in the Iberian Peninsula under scenarios RCPs 4.5 and 8.5. This climatic panorama might exacerbate the rapid decline in performance of the current threatened populations as climate warming pushes them to extirpation. Recent cases of local extinction of populations of hydrophytes in the Iberian Peninsula have already been documented [24,58]. Among the recently extinct species are Sagittaria sagittifolia L. and Oenanthe aquatica (L.) Poir., hydrophytes formerly distributed in the north of the Iberian Peninsula. The causes of their extinction are mainly associated with the loss/deterioration of their suitable habitats due to extreme climatic events such as drought and to the strong anthropogenic pressure to which the distribution areas of these species in the Iberian Peninsula are subjected [58].

It is important to note, that by neglecting other ecological processes that shape the habitat, the approach present here entails some of the issues common to niche-based ecological models [59]. For instance, our results are based on an analysis of the species' climate niches. Non-climatic constraints, such as biotic interactions, dispersal ability, and land uses are important factors that also drive the species' distribution [60,61]. Another issue is that the CNFA approach is a static method that does not capture the dynamic nature of population fluctuations over time. In addition, we must realize that the spatial scale of our approach may reduce the range of some drivers (regional/local, topographic, and microclimatic landscape features) and their effects on the study patterns [62]. However, we think that this approach is a suitable tool for a first-pass assessment of distribution patterns of species vulnerability to climate change in a spatially explicit fashion, with the potential to optimize the conservation efforts of the most vulnerable populations. 


\subsection{Management Implications}

Climate change will have far-reaching impacts on biodiversity, including increasing extinction rates [63]. Despite that increasing impacts are expected for the future, only a few studies have aimed for a general understanding of the vulnerability of rear edge populations to climate change [38]. Herein we regard the present approach as a first step towards identifying the rear edge populations that could be potentially affected by the ongoing climate change.

Depending on each species' capacity to adapt to climate change via dispersal, rapid evolution, or other processes [63], recommended actions aimed at the conservation of these populations involve monitoring and supporting adaptive responses, prioritizing the geographic locations in which vulnerability is greatest (Figure 5). On the other hand, feasible in situ conservation measures (e.g., reduce or remove threats, maximize habitat quality, reinforcement, seed collection, translocations, enhance habitat heterogeneity, improvement of landscape connectivity $[6,64]$ ) for these populations should be concentrated in those parts that are expected to have low vulnerability to climate change. In addition, areas with low vulnerability should be considered as potential suitable climate refuges from anthropogenic climate change when planning the creation of new micro-reserves or enlarging the existing ones. Climate refugia may reduce the local extirpation risk for organisms [65].

Since there are still a lot of unanswered questions about the ecological processes involved in the persistence of these populations, it is crucial to develop several research lines to provide an effective conservation plan in the long term. The vulnerability map can help to design new studies to address knowledge gaps, for example, flowering phenology, and genetic and breeding systems of the species to assess the main factors affecting female reproductive success.

\section{Conclusions}

Climate change vulnerability assessments are an important tool for understanding the threat that the anthropogenic climate change poses to species and populations. In this sense, the results of our study to this methodological field show that some threatened hydrophyte populations in the Iberian Peninsula tended to occur in less suitable environments relative to each of the species' optimal climates. This result suggests a plausible explanation to the current degree of stagnancy or regression experienced by these populations. Populations of the five species showed high sensitivity and thus vulnerability to thermal extremes and droughts. Climatic predictions for 2050 displayed that most of the examined populations will tend to occur in situations of environmental risk in the Iberian Peninsula. Therefore, actions aimed at the conservation of these populations should be prioritized in the geographic locations in which vulnerability is greatest.

Author Contributions: Conceptualization, R.E.H.-L. and J.Á.S.A.; methodology, R.E.H.-L.; software, R.E.H.-L.; validation, D.R.d.I.C. and J.Á.S.A.; formal analysis, R.E.H.-L.; investigation, R.E.H.-L.; writing—original draft preparation, R.E.H.-L.; writing—review and editing, R.E.H.-L., J.Á.S.A. and D.R.d.l.C.; visualization, R.E.H.-L.; supervision, J.Á.S.A. All authors have read and agreed to the published version of the manuscript.

Funding: This research received no external funding.

Institutional Review Board Statement: Not applicable.

Informed Consent Statement: Not applicable.

Data Availability Statement: Not applicable.

Acknowledgments: R.E.H.-L. has been granted by Consejería de Educación de la Junta de Castilla y León and Fondo Social Europeo (EDU/556/2019).

Conflicts of Interest: The authors declare no conflict of interest. 


\section{Appendix A}

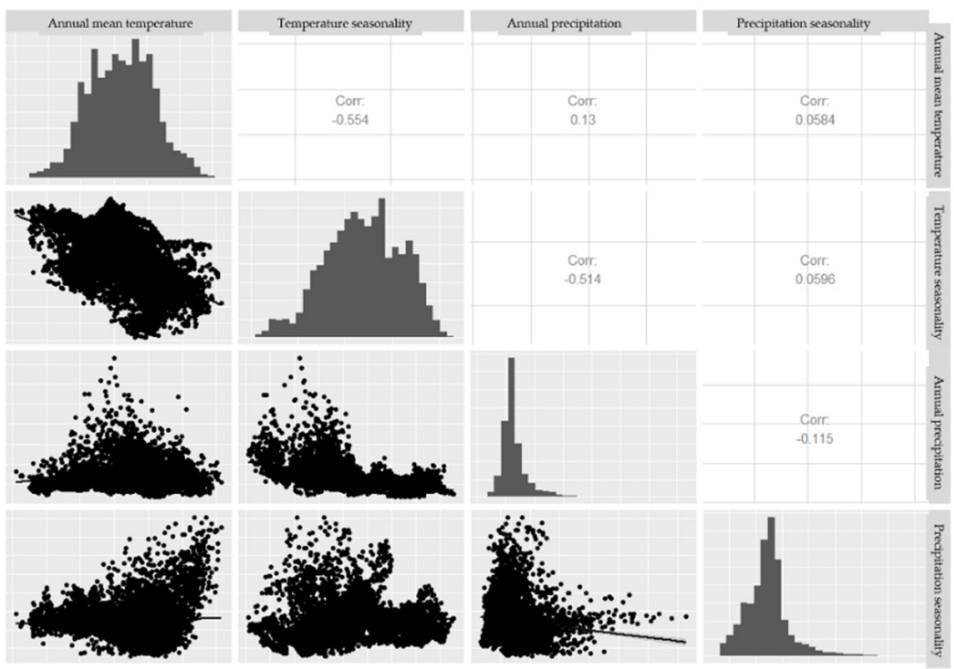

Figure A1. Pearson's correlation coefficients among the variables used to calibrate the MaxEnt and CNFA models.
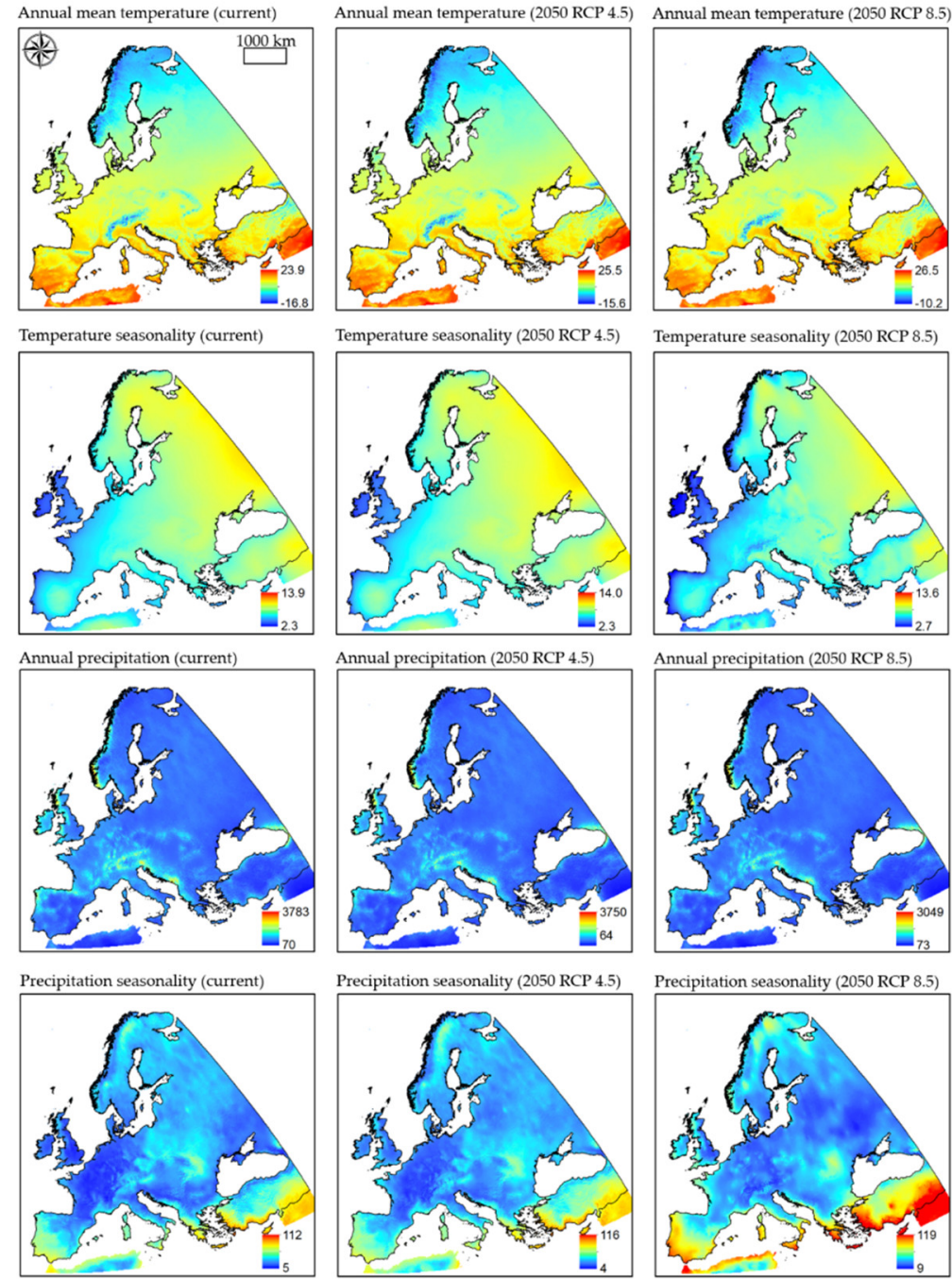

Figure A2. Spatial distribution of the climatic dataset in the study area. The future climate data were estimated from an ensemble of two global climate model projections under the representative concentration pathway (RCP) 4.5 (year 2050). 

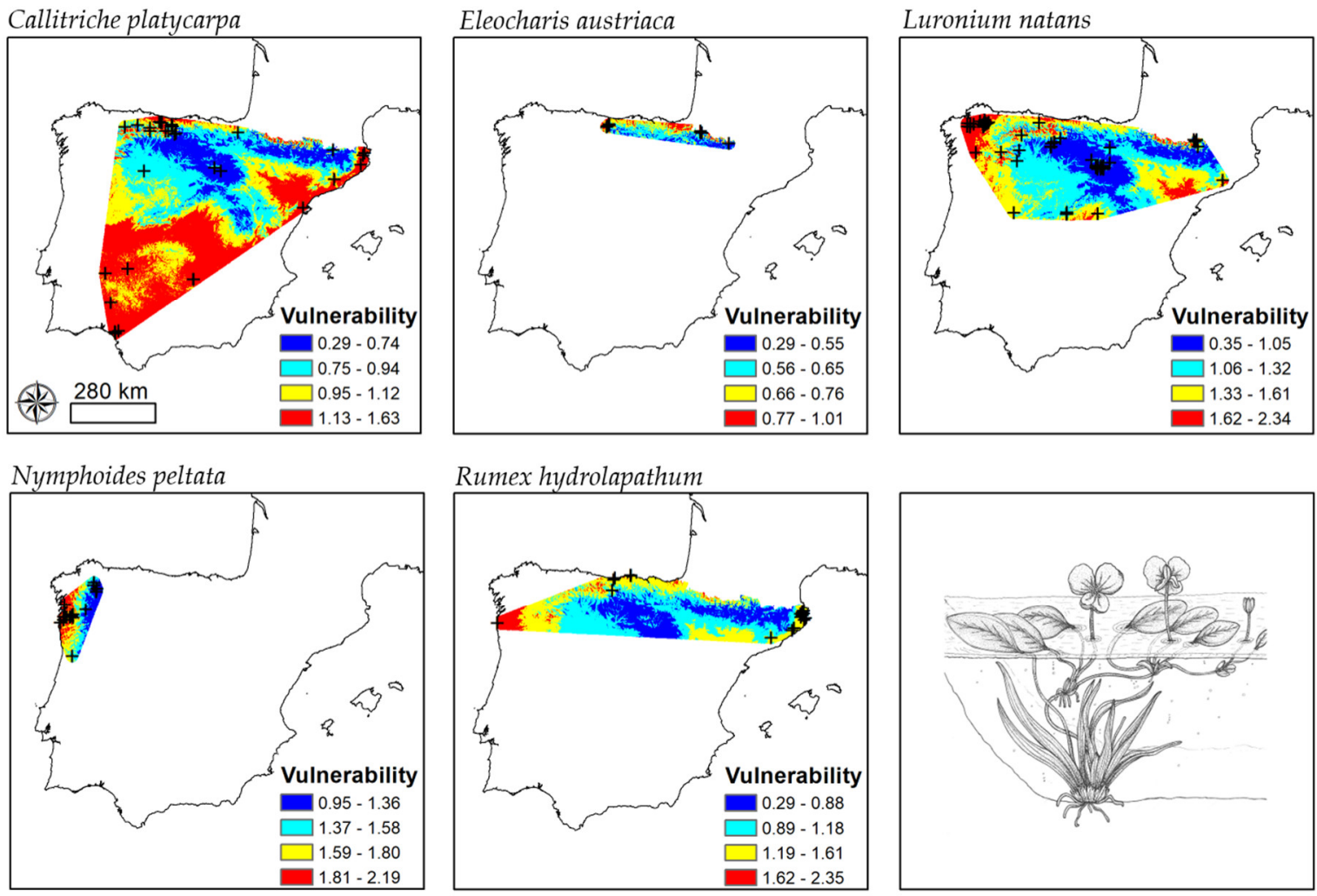

Figure A3. Predicted vulnerability across the potential habitat used by the threatened populations living on the Iberian Peninsula. The future climate scenario was estimated from an ensemble of two global climate model projections under the representative concentration pathway (RCP) 4.5 (year 2050).

\section{References}

1. Gillard, M.; Thiébaut, G.; Deleu, C.; Leroy, B. Present and future distribution of three aquatic plants taxa across the world: Decrease in native and increase in invasive ranges. Biol. Invasions 2017, 19, 2159-2170. [CrossRef]

2. Dudgeon, D. Threats to Freshwater Biodiversity in a Changing World BT. In Global Environmental Change; Freedman, B., Ed.; Springer: Dordecht, The Netherlands, 2014; pp. 243-253. ISBN 978-94-007-5784-4.

3. Alahuhta, J.; Heino, J.; Luoto, M. Climate change and the future distributions of aquatic macrophytes across boreal catchments. J. Biogeogr. 2011, 38, 383-393. [CrossRef]

4. Sala, O.E.; Stuart Chapin, F.; Armesto, J.J.; Berlow, E.; Bloomfield, J.; Dirzo, R.; Huber-Sanwald, E.; Huenneke, L.F.; Jackson, R.B.; Kinzig, A.; et al. Global Biodiversity Scenarios for the Year 2100. Science 2000, 287, 1770. [CrossRef] [PubMed]

5. Vilà-Cabrera, A.; Premoli, A.C.; Jump, A.S. Refining predictions of population decline at species' rear edges. Glob. Chang. Biol. 2019, 25, 1549-1560. [CrossRef] [PubMed]

6. Hampe, A.; Petit, R.J. Conserving biodiversity under climate change: The rear edge matters. Ecol. Lett. 2005, 8, 461-467. [CrossRef]

7. Abeli, T.; Ghitti, M.; Sacchi, R. Does ecological marginality reflect physiological marginality in plants? Plant Biosyst. Int. J. Deal. Asp. Plant Biol. 2019, 1-9. [CrossRef]

8. Thomas, C.D.; Cameron, A.; Green, R.E.; Bakkenes, M.; Beaumont, L.J.; Collingham, Y.C.; Erasmus, B.F.N.; de Siqueira, M.F.; Grainger, A.; Hannah, L.; et al. Extinction risk from climate change. Nature 2004, 427, 145-148. [CrossRef]

9. De Medeiros-Madeira, C.; Hernández-Lambraño, R.E.; Felix-Ribeiro, K.A.; Sánchez-Agudo, J.Á. Living on the edge: Do central and marginal populations of plants differ in habitat suitability? Plant Ecol. 2018, 219, 1029-1043. [CrossRef]

10. Brown, J.H.; Mehlman, D.W.; Stevens, G.C. Spatial Variation in Abundance. Ecology 1995, 76, 2028-2043. [CrossRef]

11. Urban, M.C. Accelerating extinction risk from climate change. Science 2015, 348, 571-573. [CrossRef]

12. Pironon, S.; Villellas, J.; Morris, W.F.; Doak, D.F.; García, M.B. Do geographic, climatic or historical ranges differentiate the performance of central versus peripheral populations? Glob. Ecol. Biogeogr. 2015, 24, 611-620. [CrossRef]

13. Stanton, J.C.; Shoemaker, K.T.; Pearson, R.G.; Akçakaya, H.R. Warning times for species extinctions due to climate change. Glob. Chang. Biol. 2015, 21, 1066-1077. [CrossRef] [PubMed]

14. Williams, S.E.; Shoo, L.P.; Isaac, J.L.; Hoffmann, A.A.; Langham, G. Towards an Integrated Framework for Assessing the Vulnerability of Species to Climate Change. PLoS Biol. 2008, 6, e325. [CrossRef] [PubMed]

15. Rinnan, D.S.; Lawler, J. Climate-niche factor analysis: A spatial approach to quantifying species vulnerability to climate change. Ecography 2019, 42, 1494-1503. [CrossRef]

16. Hutchinson, G.E. Concluding Remarks. Cold Spring Harb. Symp. Quant. Biol. 1957, 22, 415-427. [CrossRef] 
17. Soberón, J.; Nakamura, M. Niches and distributional areas: Concepts, methods, and assumptions. Proc. Natl. Acad. Sci. USA 2009, 106, 19644-19650. [CrossRef] [PubMed]

18. Hirzel, A.H.; Hausser, J.; Chessel, D.; Perrin, N. Ecological-Niche Factor Analysis: How to Compute Habitat-Suitability Maps Without Absence Data? Ecology 2002, 83, 2027-2036. [CrossRef]

19. Cirujano, S.; Molina, A.M.; Murillo, P.G.; Chirino, A.M. Flora Acuática Española: Hidrófitos Vasculares; Real Jardín Botánico, CSIC: Madrid, Spain, 2014; ISBN 8461686810.

20. Gentili, R.; Bacchetta, G.; Fenu, G.; Cogoni, D.; Abeli, T.; Rossi, G.; Salvatore, M.C.; Baroni, C.; Citterio, S. From cold to warm-stage refugia for boreo-alpine plants in southern European and Mediterranean mountains: The last chance to survive or an opportunity for speciation? Biodiversity 2015, 16, 247-261. [CrossRef]

21. Grzybowski, M.; Glińska-Lewczuk, K. Principal threats to the conservation of freshwater habitats in the continental biogeographical region of Central Europe. Biodivers. Conserv. 2019, 28, 4065-4097. [CrossRef]

22. Ortmann-Ajkai, A.; Csicsek, G.; Hollós, R.; Magyaros, V.; Wágner, L.; Lóczy, D. Twenty-Years' Changes of Wetland Vegetation: Effects of Floodplain-Level Threats. Wetlands 2018, 38, 591-604. [CrossRef]

23. Moreno, J.C. Lista Roja 2008 de la Flora Vascular Española; Dirección General de Medio Natural y Política Forestal (Ministerio de Medio Ambiente, y Medio Rural y Marino, y Sociedad Española de Biología de la Conservación de Plantas): Madrid, Spain, 2008; ISBN 8469173758.

24. Bañares, Á.; Blanca, G.; Gumes, J.; Moreno, J.C.; Ortiz, S. Atlas y Libro Rojo de la Flora Vascular Amenazada de España; Dirección General de Conservación de la Naturaleza: Madrid, Spain, 2010.

25. Carapeto, A.; Francisco, A.; Pereira, P.; Porto, M. Lista Vermelha da Flora Vascular de Portugal Continental; Sociedade Portuguesa de Botânica, Associação Portuguesa de Ciência da Vegetação PHYTOS e Instituto da Conservação da Natureza e das Florestas: Lisboa, Portugal, 2020; ISBN 978-972-27-2876-8.

26. IUCN The IUCN Red List of Threatened Species. Available online: http:/ / www.iucnredlist.org (accessed on 3 June 2019).

27. Tutin, T.; Heywood, V.; Burges, N.; Valentine, D.; Walters, S.; Webb, D. Flora Europaea: Lycopodiaceae to Platanaceae; Tutin, T., Heywood, V., Burges, N., Valentine, D., Walters, S., Webb, D., Eds.; The Syndics of the Cambridge University Press: New York, NY, USA, 1964.

28. Hernández-Lambraño, R.E.; González-Moreno, P.; Sánchez-Agudo, J.Á. Towards the top: Niche expansion of Taraxacum officinale and Ulex europaeus in mountain regions of South America. Australia Ecol. 2017, 42, 577-589. [CrossRef]

29. Karger, D.N.; Conrad, O.; Böhner, J.; Kawohl, T.; Kreft, H.; Soria-Auza, R.W.; Zimmermann, N.E.; Linder, H.P.; Kessler, M. Climatologies at high resolution for the earth's land surface areas. Sci. Data 2017, 4, 170122. [CrossRef] [PubMed]

30. Zuckerberg, B.; Strong, C.; LaMontagne, J.M.; St. George, S.; Betancourt, J.L.; Koenig, W.D. Climate Dipoles as Continental Drivers of Plant and Animal Populations. Trends Ecol. Evol. 2020, 35, 440-453. [CrossRef] [PubMed]

31. ESRI ARCMAP 10.3.1. 2015. Available online: https://support.esri.com/en/products/desktop/arcgis-desktop/arcmap/10-3-1. (accessed on 3 June 2019).

32. Naujokaitis-Lewis, I.R.; Curtis, J.M.R.; Tischendorf, L.; Badzinski, D.; Lindsay, K.; Fortin, M.-J. Uncertainties in coupled species distribution-metapopulation dynamics models for risk assessments under climate change. Divers. Distrib. 2013, 19, 541-554. [CrossRef]

33. Buisson, L.; Thuiller, W.; Casajus, N.; Lek, S.; Grenoillet, G. Uncertainty in ensemble forecasting of species distribution. Glob. Chang. Biol. 2010, 16, 1145-1157. [CrossRef]

34. Gent, P.R.; Danabasoglu, G.; Donner, L.J.; Holland, M.M.; Hunke, E.C.; Jayne, S.R.; Lawrence, D.M.; Neale, R.B.; Rasch, P.J.; Vertenstein, M.; et al. The Community Climate System Model Version 4. J. Clim. 2011, 24, 4973-4991. [CrossRef]

35. Martin, G.M.; Bellouin, N.; Collins, W.J.; Culverwell, I.D.; Halloran, P.R.; Hardiman, S.C.; Hinton, T.J.; Jones, C.D.; McDonald, R.E.; McLaren, A.J.; et al. The HadGEM2 family of Met Office Unified Model climate configurations. Geosci. Model Dev. 2011, 4, 723-757. [CrossRef]

36. Albuquerque, F.; Benito, B.; Rodriguez, M.Á.M.; Gray, C. Potential changes in the distribution of Carnegiea gigantea under future scenarios. PeerJ 2018, 6, e5623. [CrossRef] [PubMed]

37. Harris, R.M.B.; Grose, M.R.; Lee, G.; Bindoff, N.L.; Porfirio, L.L.; Fox-Hughes, P. Climate projections for ecologists. WIREs Clim. Chang. 2014, 5, 621-637. [CrossRef]

38. Thuiller, W.; Lavorel, S.; Araújo, M.B.; Sykes, M.T.; Prentice, I.C. Climate change threats to plant diversity in Europe. Proc. Natl. Acad. Sci. USA 2005, 102, 8245-8250. [CrossRef] [PubMed]

39. Giorgi, F.; Lionello, P. Climate change projections for the Mediterranean region. Glob. Planet. Chang. 2008, 63, 90-104. [CrossRef]

40. Phillips, S.J.; Anderson, R.P.; Dudík, M.; Schapire, R.E.; Blair, M.E. Opening the black box: An open-source release of Maxent. Ecography 2017, 40, 887-893. [CrossRef]

41. Elith, J.; Phillips, S.J.; Hastie, T.; Dudík, M.; Chee, Y.E.; Yates, C.J. A statistical explanation of MaxEnt for ecologists. Divers. Distrib. 2011, 17, 43-57. [CrossRef]

42. Elith, J.; Graham, C.H.; Anderson, R.P.; Dudík, M.; Ferrier, S.; Guisan, A.; Hijmans, R.J.; Huettmann, F.; Leathwick, J.R.; Lehmann, A.; et al. Novel methods improve prediction of species' distributions from occurrence data. Ecography 2006, $29,129-151$. [CrossRef]

43. Wisz, M.S.; Hijmans, R.J.; Li, J.; Peterson, A.T.; Graham, C.H.; Guisan, A. Effects of sample size on the performance of species distribution models. Divers. Distrib. 2008, 14, 763-773. [CrossRef] 
44. Elith, J.; Leathwick, J.R. Species Distribution Models: Ecological Explanation and Prediction Across Space and Time. Annu. Rev. Ecol. Evol. Syst. 2009, 40, 677-697. [CrossRef]

45. Franklin, J. Mapping Species distributions: Spatial Inference and Prediction; Cambridge University Press: New York, NY, USA, 2010; ISBN 1139485296.

46. Cobos, M.E.; Peterson, A.T.; Barve, N.; Osorio-Olvera, L. kuenm: An R package for detailed development of ecological niche models using Maxent. PeerJ 2019, 7, e6281. [CrossRef]

47. Pacifici, M.; Foden, W.B.; Visconti, P.; Watson, J.E.M.; Butchart, S.H.M.; Kovacs, K.M.; Scheffers, B.R.; Hole, D.G.; Martin, T.G.; Akçakaya, H.R.; et al. Assessing species vulnerability to climate change. Nat. Clim. Chang. 2015, 5, 215-224. [CrossRef]

48. Quintero, I.; Wiens, J.J. Rates of projected climate change dramatically exceed past rates of climatic niche evolution among vertebrate species. Ecol. Lett. 2013, 16, 1095-1103. [CrossRef]

49. Basille, M.; Calenge, C.; Marboutin, É.; Andersen, R.; Gaillard, J.M. Assessing habitat selection using multivariate statistics: Some refinements of the ecological-niche factor analysis. Ecol. Model. 2008, 211, 233-240. [CrossRef]

50. Raia, P.; Mondanaro, A.; Melchionna, M.; Di Febbraro, M.; Diniz-Filho, J.A.F.; Rangel, T.F.; Holden, P.B.; Carotenuto, F.; Edwards, N.R.; Lima-Ribeiro, M.S. Past extinctions of Homo species coincided with increased vulnerability to climatic change. One Earth 2020, 3, 480-490. [CrossRef]

51. Wang, W.-T.; Guo, W.-Y.; Jarvie, S.; Svenning, J.-C. The fate of Meconopsis species in the Tibeto-Himalayan region under future climate change. Ecol. Evol. 2021, 11, 887-899. [CrossRef] [PubMed]

52. Sutton, L.J.; Anderson, D.L.; Franco, M.; McClure, C.J.W.; Miranda, E.B.P.; Vargas, F.H.; Vargas González, J.D.J.V.; Puschendorf, R. Geographic range estimates and environmental requirements for the harpy eagle derived from spatial models of current and past distribution. Ecol. Evol. 2021, 11, 481-497. [CrossRef]

53. R Core Team. R: A Language and Environment for Statistical Computing; R Foundation for Statistical Computing: Vienna, Austria, 2019.

54. Allen, C.D.; Macalady, A.K.; Chenchouni, H.; Bachelet, D.; McDowell, N.; Vennetier, M.; Kitzberger, T.; Rigling, A.; Breshears, D.D.; Hogg, E.H.; et al. A global overview of drought and heat-induced tree mortality reveals emerging climate change risks for forests. For. Ecol. Manag. 2010, 259, 660-684. [CrossRef]

55. Pironon, S.; Papuga, G.; Villellas, J.; Angert, A.L.; García, M.B.; Thompson, J.D. Geographic variation in genetic and demographic performance: New insights from an old biogeographical paradigm. Biol. Rev. 2017, 92, 1877-1909. [CrossRef]

56. Eckert, C.G.; Samis, K.E.; Lougheed, S.C. Genetic variation across species' geographical ranges: The central-marginal hypothesis and beyond. Mol. Ecol. 2008, 17, 1170-1188. [CrossRef]

57. Sagarin, R.D.; Gaines, S.D.; Gaylord, B. Moving beyond assumptions to understand abundance distributions across the ranges of species. Trends Ecol. Evol. 2006, 21, 524-530. [CrossRef]

58. Aedo, C.; Medina, L.; Barberá, P.; Fernández-Albert, M. Extinctions of vascular plants in Spain. Nord. J. Bot. 2015, 33, 83-100. [CrossRef]

59. Jiménez-Valverde, A.; Lobo, J.M.; Hortal, J. Not as good as they seem: The importance of concepts in species distribution modelling. Divers. Distrib. 2008, 14, 885-890. [CrossRef]

60. Hernández-Lambraño, R.E.; González-Moreno, P.; Sánchez-Agudo, J.Á. Environmental factors associated with the spatial distribution of invasive plant pathogens in the Iberian Peninsula: The case of Phytophthora cinnamomi Rands. For. Ecol. Manag. 2018, 419-420, 101-109. [CrossRef]

61. Osorio-Olvera, L.; Soberón, J.; Falconi, M. On population abundance and niche structure. Ecography 2019, 42, 1415-1425. [CrossRef]

62. Oldfather, M.F.; Kling, M.M.; Sheth, S.N.; Emery, N.C.; Ackerly, D.D. Range edges in heterogeneous landscapes: Integrating geographic scale and climate complexity into range dynamics. Glob. Chang. Biol. 2020, 26, 1055-1067. [CrossRef]

63. Foden, W.B.; Butchart, S.H.M.; Stuart, S.N.; Vié, J.-C.; Akçakaya, H.R.; Angulo, A.; DeVantier, L.M.; Gutsche, A.; Turak, E.; Cao, L.; et al. Identifying the World's Most Climate Change Vulnerable Species: A Systematic Trait-Based Assessment of all Birds, Amphibians and Corals. PLoS ONE 2013, 8, e65427. [CrossRef] [PubMed]

64. Oliver, T.; Roy, D.B.; Hill, J.K.; Brereton, T.; Thomas, C.D. Heterogeneous landscapes promote population stability. Ecol. Lett. 2010, 13, 473-484. [CrossRef] [PubMed]

65. Dobrowski, S.Z. A climatic basis for microrefugia: The influence of terrain on climate. Glob. Chang. Biol. 2011, 17, 1022-1035. [CrossRef] 